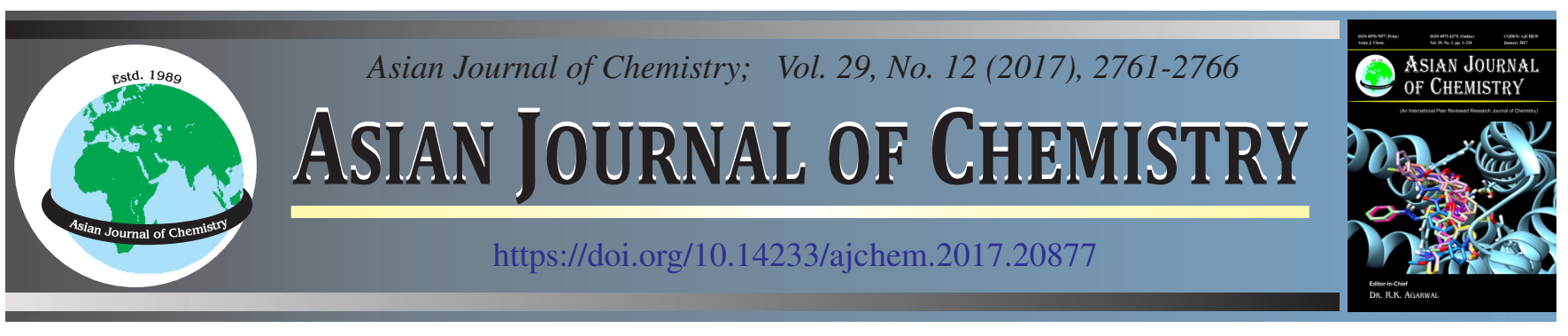

\title{
Adsorption of Lead and Copper by Carbon Black and Sodium Bentonite Composite Material: A Study on Adsorption Isotherms and Kinetics
}

\author{
Haleden Chiririwa ${ }^{1, *}$, Thabo Matthews ${ }^{2}$, Bothwell Nyoni ${ }^{2}$, Stephen Majoni $^{2}$ and Bobby Naidoo ${ }^{1}$
}

${ }^{1}$ Biosorption and Water Research Laboratory Department of Chemistry, Vaal University of Technology, Private Bag X021, Vanderbijlpark, 1911, Andries Potgieter Blvd, South Africa

${ }^{2}$ Department of Applied Chemistry, National University of Science and Technology, Bulawayo, Zimbabwe

*Corresponding author: Fax +27 16950 9000; Tel.: +27 16950 6742; E-mail: harrychiririwa@yahoo.com

The efficiency of using a composite of carbon black and sodium bentonite in treating drinking water contaminated with lead and copper ions was analyzed. The effects of $\mathrm{pH}$, contact time, concentration and adsorbent dosage using an adsorbent composite of $20 \%$ sodium bentonite and $80 \%$ carbon black were studied. The adsorption data was analyzed with respect to Langmuir, Freundlich and Temkin isotherms. The data fits well with the Langmuir isotherm model with high coefficients of determination for both metal ions adsorption. The adsorption kinetics follows a pseudo second-order model for both metal ions. The maximum metal ion uptake $\left(\mathrm{q}_{\max }\right)$ of composite adsorbent is 7.69 and $0.80 \mathrm{mg} / \mathrm{g}$ for lead and copper, respectively.

Keywords: Adsorption, Carbon black, Sodium bentonite, Drinking water, Isotherms, Kinetics.

\section{INTRODUCTION}

It is estimated that around year 2025, up to 3.5 billion people of the world population will be living in water stressed countries [1]. Therefore, the extent of water recycling and purification is expected to increase to cater for the growing demand of safe drinking water. The concentrations of metal ions in waters from underground and recycling sources may sometimes exceed the required sanitary standards [2]. Industrial wastewater is a major source of environmental water pollution and limits the use of underground water sources unless if proper water management systems are set up [3]. Industries such as paint, lead smelting, battery manufacturing and mining generate wastewater with concentrations of copper, lead and other metals high enough to cause upsets in the ecosystem [4]. Lead, copper and other heavy metals find their way into the drinking water system largely through industrial discharge and surface runoff [5,6]. Also, piping systems for drinking water are made of either copper or lead which corrodes into the water due to age. Drinking water from river and aquifer sources with lead and copper concentrations of above 0.035 and $0.2 \mathrm{ppm}$, respectively, has been reported [1,5-7]. Lead is absorbed into the human blood stream and accumulates in bones, it has been reported to be the cause of cardiovascular diseases, fetus development, memory and concentration problems and nervous system disorders $[8,9]$. Copper has a lesser negative effect on humans as compared to lead, however, copper affects most organisms in the environment [1]. Various methods for removing lead and copper from wastewaters have been studied, namely reverse osmosis, electrodialysis, ion exchange and chemical precipitation [9].

The use of carbon black in adsorbing dyes from wastewater has been reported and it was shown that poly(vinyl alcohol) coated carbon black has the ability to remedy water with considerable dye concentrations [10]. The same study also revealed that the kinetics of adsorption best fit the Langmuir and Freundlich isotherms. The use of sodium bentonite in the treatment of oil-water emulsions has been studied [11]. Researchers reported that bentonite was effective as an adsorbent for the removal of oil, the removal percentage increased as the contact time was increased.

In this work, the use of a composite adsorbent of sodium bentonite and carbon black in removal of lead and copper from drinking water is investigated. The factors affecting the adsorption process e.g. solution $\mathrm{pH}$, contact time, solution initial concentration and adsorbent dosage are examined. Adsorption isotherms and kinetic models are analyzed for the experimental data obtained.

\section{EXPERIMENTAL}

Carbon black, bentonite and stock solutions of $\mathrm{Cu}^{2+}$ and $\mathrm{Pb}^{2+}$ were obtained from commercial merchants, A.I. Davis (Pvt.) Ltd. and William Smith \& Gourock. The working 
solutions were prepared from the stock solutions by dilution to the desired concentrations.

Preparation of adsorbent material: Bentonite (1000 g) was heated at $350{ }^{\circ} \mathrm{C}$ in an oven for $2 \mathrm{~h}$ and then socked in $2 \mathrm{M}$ $\mathrm{NaOH}$ for $0.5 \mathrm{~h}$ so as to increase the adsorption capacity. The prepared clay sample was mixed with $2 \mathrm{M} \mathrm{NaOH}$ in the ratio of 1:5 (m/v). The sample was filtered and then rinsed with distilled water several times until the $\mathrm{pH}$ became neutral. The sample was then dried in an oven at $100^{\circ} \mathrm{C}$ for $2 \mathrm{~h} \mathrm{[12].} \mathrm{Carbon}$ black was used in the form of a powder. The composite adsorbent was prepared by mixing $4 \mathrm{~g}$ of carbon black per gram of the prepared sodium bentonite sample.

Effect of pH on metal adsorption: Composite adsorbent $(0.8 \mathrm{~g})$ was added to each of four $250 \mathrm{~mL}$ volumetric flasks containing $100 \mathrm{~mL}$ of $25 \mathrm{ppm}$ lead solution. Another similar set containing $2 \mathrm{ppm}$ copper ions was set up. The $\mathrm{pH}$ of the solutions was adjusted to 2, 4, 6 and 8 using $0.1 \mathrm{M} \mathrm{HCl}$ or $\mathrm{NaOH}$ and monitored using a $\mathrm{pH}$ meter (Corning $\mathrm{pH}$ meter 220 , USA). The mixtures were agitated at $160 \mathrm{rpm}$ at room temperature and atmospheric pressure $\left(25^{\circ} \mathrm{C}\right)$ for $2 \mathrm{~h}$. At the end of the experiment, the solution was filtered to remove the adsorbent and the metal ion concentration analyzed using AAS. An average of three AAS measurements was taken as the residual metal ion concentration value.

Effect of dosage on metal adsorption: Varying masses of the adsorbent $(0.1-1 \mathrm{~g})$ were added to $100 \mathrm{~mL}$ (in stoppered conical flask) of $25 \mathrm{ppm}$ lead solution and the mixture was agitated at $160 \mathrm{rpm}$ for $2 \mathrm{~h}$. The mixture was filtered and the residual metal ion concentrations of the filtrate were determined using AAS. The process was then repeated using 2 ppm copper ion solutions. An average of three AAS measurements was taken as the residual metal ion concentration value.

Effect of initial concentration on metal adsorption: Adsorbent $(0.8 \mathrm{~g})$ was added to $100 \mathrm{~mL}$ of aqueous solutions in the concentration range of 10 to $25 \mathrm{ppm}$ and 0.8 to $2 \mathrm{ppm}$ for lead and copper ions, respectively. The mixture was agitated at $160 \mathrm{rpm}$. Samples were extracted at every $20 \mathrm{~min}$ intervals and filtered before analysis. An average of three AAS measurements was taken as the residual metal ion concentration value.

Batch equilibrium study: The adsorption isotherm experiment was carried out in batch process using a $250 \mathrm{~mL}$ stoppered conical flask. A known mass (0.2-0.8g) of adsorbent was added to $100 \mathrm{~mL}$ metal containing solution. The mixtures were agitated for $2 \mathrm{~h}$ since initial experiments managed to show that equilibrium was attained within that time frame. The equilibrium concentrations of $\mathrm{Pb}^{2+}$ and $\mathrm{Cu}^{2+}$ in each sample were determined using AAS after filtration. The amount of metal adsorbed by the adsorbent at equilibrium $\left(\mathrm{q}_{\mathrm{e}}\right)$ and the percentage removal were calculated according to eqn. 1 and 2, respectively.

$$
\begin{gathered}
\mathrm{q}_{\mathrm{e}}=\frac{\left(\mathrm{C}_{\mathrm{i}}-\mathrm{C}_{\mathrm{e}}\right) \mathrm{V}}{\mathrm{M}} \\
\operatorname{Removal}(\%)=\left(\frac{\mathrm{C}_{\mathrm{i}}-\mathrm{C}_{\mathrm{e}}}{\mathrm{C}_{\mathrm{i}}}\right) \times 100
\end{gathered}
$$

where $\mathrm{C}_{\mathrm{i}}$ and $\mathrm{C}_{\mathrm{e}}$ are the initial and equilibrium concentrations $(\mathrm{ppm})$ of the metal ions, respectively, $\mathrm{V}$ is the volume $(\mathrm{mL})$ of the solution and $\mathrm{M}$ is the mass of the adsorbent $(\mathrm{g})$.
Statistical analysis: The measured quantities were reported as an average of three readings. Linear plots with the best $\mathrm{R}^{2}$ values were chosen as the best representation. A statistical method was used for calculating the margin of errors for the slope and $y$-intercept of the graphs generated [13]. The process parameters evaluated from the slopes and y-intercepts of graphs were reported with their margin of errors at $95 \%$ confidence level.

\section{RESULTS AND DISCUSSION}

Effect of $\mathbf{p H}$ on metal adsorption: The solution $\mathrm{pH}$ is an important parameter which affects an adsorption process as it is closely linked to the surface charge of the adsorbent. Fig. 1 shows the effect of $\mathrm{pH}$ on the adsorption of each of the metal ions. For the $\mathrm{pH}$ range investigated ( $\mathrm{pH} 2$ up to 8), the percentage removal of both metal ions increases with $\mathrm{pH}$ in the range $\mathrm{pH} 2$ up to 6 thereafter the percentage removal decreases. The optimum $\mathrm{pH}$ value for both metals was found to be 6 . These results confirm what other researchers found, where the percentage adsorption increases as the $\mathrm{pH}$ increased up to a certain optimum $\mathrm{pH}$ value [14]. At low $\mathrm{pH}$ values, the solution is characterized by high $\mathrm{H}^{+}$ion concentration which results in a high positive charge density on the surface of the adsorbent which repels the positively charged metal ions. On the other hand, at higher $\mathrm{pH}$ values the dominant $\mathrm{OH}^{-}$ions on the surface of the adsorbent induce a high negative charge density which attracts more metal ions.

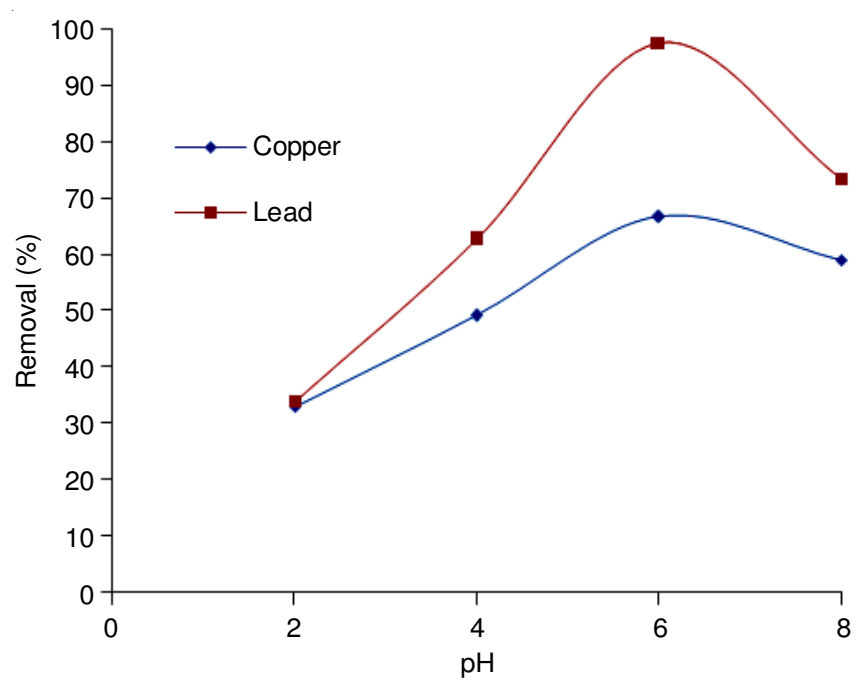

Fig. 1. Effect of $\mathrm{pH}$ on the adsorption of lead(II) and copper(II) (Conditions: $0.8 \mathrm{~g}$ adsorbent dosage, $160 \mathrm{rpm}, 2 \mathrm{~h}$ agitation time, temperature $25^{\circ} \mathrm{C}$ ) [one experimental run for each graph, average of three AAS measurements for each data point]

Effect of dosage on metal adsorption: The amount of adsorbent in the mixture translates into the number of active sites available for the adsorption process; therefore the metal uptake is expected to increase with an increase in the amount of adsorbent. This phenomenon is shown in Fig. 2, for $\mathrm{pH} 6$, as the amount of adsorbent increases from 0 to $0.8 \mathrm{~g}$, the percentage adsorption of lead and copper ions also increases from 0 to $70 \%$ and 0 to $83 \%$, respectively. This phenomenon has been attributed to the overcrowding of the adsorbent particles as the dosage is increased thereby creating an overlap of adsorption sites [15]. Thus, $0.8 \mathrm{~g}$ of adsorbent was selected as adsorbent dosage for 
all the experiments that required a fixed amount of adsorbent because of the high percentage removal (Fig. 2).

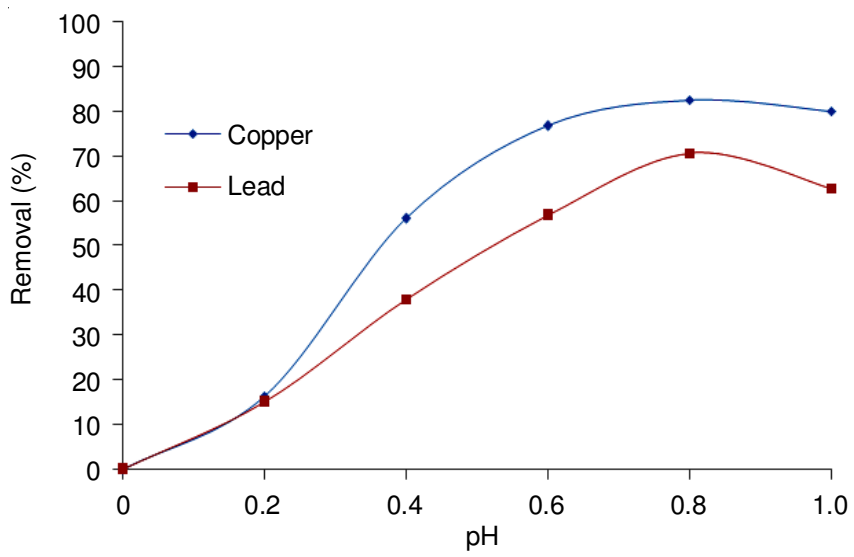

Fig. 2. Effect of adsorbent dosage on the adsorption of lead(II) and copper(II) (Conditions: 25 ppm lead \& 2 ppm copper, 160 rpm, 2 h agitation time, temperature $25^{\circ} \mathrm{C}$ ) [one experimental run for each graph, average of three AAS measurements for each data point]

Effect of contact time on metal adsorption: Contact time is an important variable for adsorption experiments and actual process design. A short contact time means less chances of attaining equilibrium and a longer contact time means the higher the chances of the metal-adsorbent complexes formed breaking down into individual species. Figs. 3 and 4 show the adsorption of lead and copper ions respectively, as a function of contact time for varying concentrations. It is shown that for both metal ions adsorption, the percentage removal increases rapidly up to $1 \mathrm{~h}$ then stays constant for the remaining time up to $2 \mathrm{~h}$. According to Figs. 3 and 4, the equilibrium is attained after $1 \mathrm{~h}$ and the concentration of the metal ions in solution stays constant up to $2 \mathrm{~h}$. Therefore, for all the experiments where equilibrium was supposed to be attained, a contact time of $2 \mathrm{~h}$ was used.

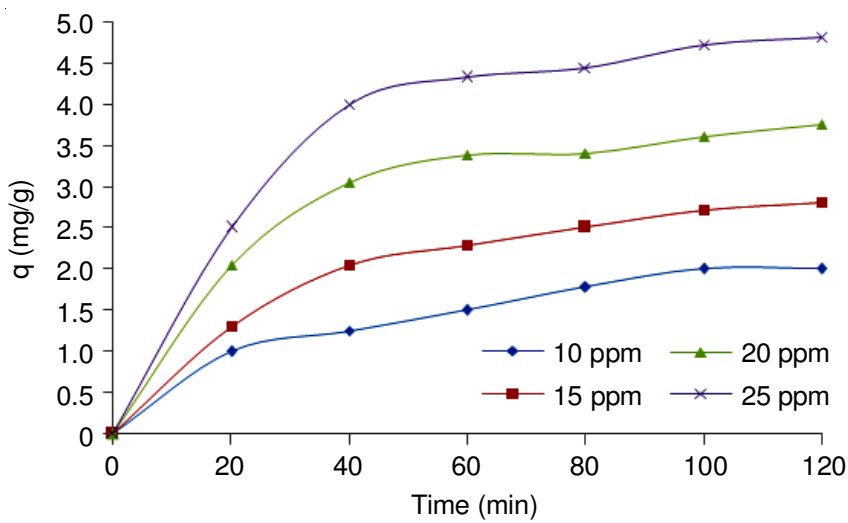

Fig. 3. Effect of contact time at differential initial concentration on the adsorption of lead(II) (Conditions: $0.8 \mathrm{~g}$ adsorbent dosage, $160 \mathrm{rpm}$, $2 \mathrm{~h}$ agitation time, temperature $25^{\circ} \mathrm{C}$ ) [one experimental run for each graph, average of three AAS measurements for each data point]

Effect of initial concentration on metal adsorption: The relationship between initial concentration and the percentage removal of metal for a dosage of $0.8 \mathrm{~g}$ adsorbent in $100 \mathrm{~mL}$ solution is shown in Fig. 3 and 4. Generally, according to eqns. 1 and 2 , the initial concentration is a parameter affecting the

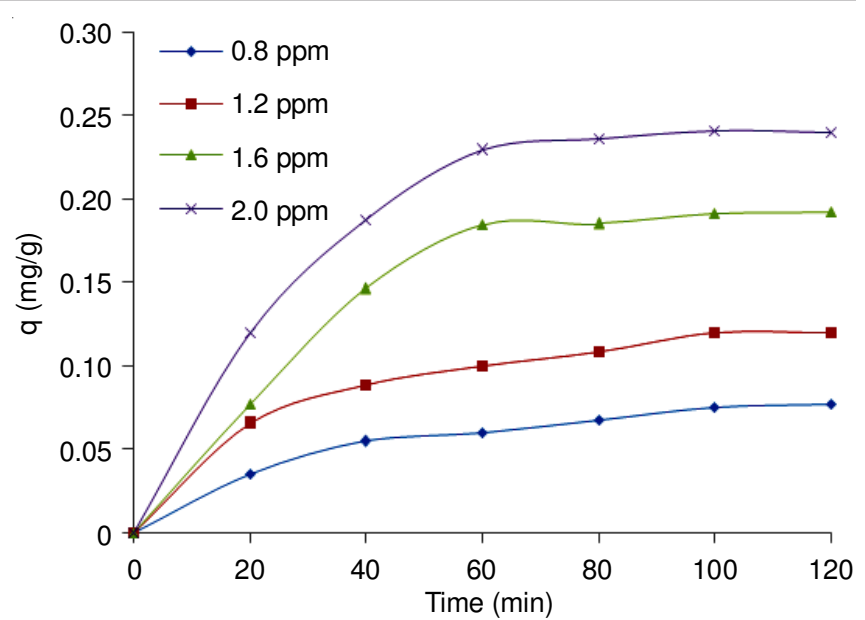

Fig. 4. Effect of contact time at differential initial concentration on the adsorption of copper(II) (Conditions: $0.8 \mathrm{~g}$ adsorbent dosage, 160 $\mathrm{rpm}, 2 \mathrm{~h}$ agitation time, temperature $25^{\circ} \mathrm{C}$ ) [one experimental run for each graph, average of three AAS measurements for each data point]

amount of metal uptake and percentage removal. The magnitude of the difference between initial and equilibrium concentration, called the concentration gradient, directly affects the amount of metal adsorbed. The results presented in Fig.s 3 and 4 indicate that as the concentration of the solution is increased, the amount of metal ion adsorbed per unit adsorbent mass increases. The equilibrium adsorption of lead increased from 0.98 to 2.31 $\mathrm{mg} / \mathrm{g}$ with an increase of 10 to $25 \mathrm{ppm}$ lead ion concentration, also the equilibrium adsorption of copper increased from 0.07 to $0.24 \mathrm{mg} / \mathrm{g}$ with an increase of 0.8 to $2 \mathrm{ppm}$ copper ion concentration.

Adsorption isotherms: The adsorption isotherms of the process were evaluated. The experimental data was fitted into three models, Langmuir, Freundlich and Temkin models which have been widely used to describe metal ion adsorption processes $[16,17]$.

Langmuir isotherm: The Langmuir isotherm was developed based on the assumption that each site can accommodate only one molecule of the adsorbate with no molecule migration and the energy of adsorption is constant all over the surface [18]. The maximum adsorption occurs when the monolayer of adsorbate molecules becomes saturated on the adsorbent surface and having a constant energy of adsorption. The linear form of the model is:

$$
\frac{1}{q_{e}}=\frac{1}{q_{\max }}+\frac{1}{q_{\max } b_{e}}
$$

where $\mathrm{q}_{\mathrm{e}}$ is the equilibrium metal ion concentration on the adsorbent ( $\mathrm{mg} / \mathrm{g}), \mathrm{q}_{\max }$ is the maximum adsorption capacity on monolayer adsorbent saturation $(\mathrm{mg} / \mathrm{g}), \mathrm{C}_{\mathrm{e}}$ is the equilibrium metal ion concentration in solution ( $\mathrm{ppm}$ ), $\mathrm{b}$ is the Langmuir affinity constant $(\mathrm{L} / \mathrm{mg})$. A plot of $1 / \mathrm{q}_{\mathrm{e}}$ against $1 / \mathrm{C}_{\mathrm{e}}$ for each metal ion gave a straight line with a slope of $1 / \mathrm{q}_{\max }=11.8$ and 9.54 and $y$-intercept of $1 / \mathrm{q}_{\max }=0.13$ and 1.25 for lead and copper, respectively (figures not shown).

The dimensionless quantity, the separation factor, $\mathrm{R}_{\mathrm{L}}$ (eqn. 4) was used to confirm the favourableness of the adsorption process for the conditions used in the experiment. 


$$
\mathrm{R}_{\mathrm{L}}=\frac{1}{1+\mathrm{bC}_{0}}
$$

where $C_{o}$ is the highest initial metal ion concentration in solution. Assuming the adsorption follows the Langmuir isotherm, the parameters are listed in Table- $1 . \mathrm{R}_{\mathrm{L}}$ values are less than 1 indicating that lead and copper adsorption using the composite adsorbate at room temperature and pressure is favourable. The adsorption capacity of the adsorbent is large for lead, 7.69 compared to $0.80 \mathrm{mg} / \mathrm{g}$ for copper. This implies that there is higher adsorbate-adsorbent affinity between the composite material and lead. The results compare well with previous studies where low values of $\mathrm{q}_{\max }$ and $\mathrm{b}$ for adsorption of copper onto natural bentonite were reported [16].

\section{TABLE-1}

LANGMUIR PARAMETERS FOR THE ADSORPTION OF LEAD AND COPPER AT $25^{\circ} \mathrm{C}$

\begin{tabular}{ccc}
\hline Parameter & Lead adsorption & Copper adsorption \\
\hline $\mathrm{q}_{\max }(\mathrm{mg} / \mathrm{g})$ & 7.690 & 0.800 \\
$\mathrm{~b}(\mathrm{~L} / \mathrm{mg})$ & 0.011 & 0.130 \\
$\mathrm{R}_{\mathrm{L}}$ & 0.780 & 0.790 \\
$\mathrm{R}^{2}$ & 0.920 & 0.916 \\
\hline
\end{tabular}

Freundlich isotherm: The Freundlich isotherm was developed so as to model the multilayer adsorption on heterogeneous surfaces [19]. The linear form of the model is:

$$
\ln \mathrm{q}_{\mathrm{e}}=\ln \mathrm{k}_{\mathrm{f}}+\left(\frac{1}{\mathrm{n}}\right) \ln \mathrm{C}_{\mathrm{e}}
$$

where $\mathrm{q}_{\mathrm{e}}$ is the amount of metal ion adsorbed at equilibrium $(\mathrm{mg} / \mathrm{g}), \mathrm{C}_{\mathrm{e}}$ is the concentration of the adsorbate at equilibrium $(\mathrm{ppm}), \mathrm{k}_{\mathrm{f}}$ is the Freundlich constant related to adsorption capacity and $\mathrm{n}$ is a dimensionless heterogeneity coefficient. A plot of $\ln \mathrm{q}_{\mathrm{e}}$ against $\mathrm{In}_{\mathrm{e}}$ for each metal ion gave a straight line with a slope of $1 / \mathrm{n}=0.98$ and 0.96 and $y$-intercept of $\mathrm{In} \mathrm{k}_{\mathrm{f}}=-2.52$ and -2.35 for lead and copper adsorption, respectively (figure not shown). The Freundlich parameters are shown in Table-2. The values of the coefficient (n) are greater than one, indicating that according to the Freundlich model, the process of adsorption of both metal ions is favourable. The $\mathrm{k}_{\mathrm{f}}$ values for both metals indicate that the capacity of the adsorbent is low.

\begin{tabular}{ccc}
\multicolumn{3}{c}{ TABLE-2 } \\
FREUNDLICH PARAMETERS FOR THE \\
ADSORPTION OF LEAD AND COPPER AT $25{ }^{\circ} \mathrm{C}$ \\
\hline Parameter & Lead adsorption & Copper adsorption \\
\hline $\mathrm{n}$ & 1.020 & 1.040 \\
$\mathrm{k}_{\mathrm{f}}(\mathrm{mg} / \mathrm{g})$ & 0.080 & 0.100 \\
$\mathrm{R}^{2}$ & 0.923 & 0.853 \\
\hline
\end{tabular}

Temkin isotherm: The effects of adsorbate interactions on adsorption were investigated and it was noted that in these interactions the energy of adsorption of all the molecules in a layer is a function of temperature and it will decrease linearly as the adsorbent surface is loaded with adsorbate. The linear form of the model [20] is as follows:

$$
\mathrm{q}_{\mathrm{e}}=\frac{\mathrm{RT}}{\mathrm{b}} \ln \mathrm{A}+\frac{\mathrm{RT}}{\mathrm{b}} \ln \mathrm{C}_{\mathrm{e}}
$$

where $\mathrm{q}_{\mathrm{e}}$ is the amount of metal ion adsorbed at equilibrium $(\mathrm{mg} / \mathrm{g}), \mathrm{C}_{\mathrm{e}}$ is the concentration of adsorbate at equilibrium ( $\left.\mathrm{ppm}\right)$, $\mathrm{b}$ is the Temkin constant related to heat of adsorption $(\mathrm{J} / \mathrm{mol})$, A is the Temkin isotherm constant $(\mathrm{L} / \mathrm{g}), \mathrm{R}$ is the gas constant $(8.314 \mathrm{~J} / \mathrm{mol} . \mathrm{K})$ and $\mathrm{T}$ is the absolute temperature $(\mathrm{K})$. A plot of $\mathrm{q}_{\mathrm{e}}$ against $\mathrm{In} \mathrm{C}_{\mathrm{e}}$ for each metal ion gave a straight line (figure not shown). The constants $\mathrm{A}$ and $\mathrm{b}$ are reported in Table-3, as $0.29 \mathrm{~L} / \mathrm{g}$ and $3260 \mathrm{~J} / \mathrm{mol}$ respectively, for lead and $4.02 \mathrm{~L} / \mathrm{g}$ and $35907 \mathrm{~J} / \mathrm{mol}$ respectively, for copper. Assuming the adsorption process follows the Temkin model, the interactions between the metal ions and the adsorbent are more pronounced for copper than for lead. This phenomena is evidenced by a comparison of the values of Temkin constant, ( $b=3260$ and $35907 \mathrm{~J} / \mathrm{mol}$ for lead and copper, respectively) which is a direct measure of the maximum binding energy for each of the metals' adsorption processes.

\begin{tabular}{ccc} 
TABLE-3 \\
TEMKIN PARAMETERS FOR THE ADSORPTION OF LEAD \\
\multicolumn{3}{c}{ AND COPPER AT ROOM TEMPERATURE AND PRESSURE } \\
\hline Parameter & Lead adsorption & Copper adsorption \\
\hline $\mathrm{T}(\mathrm{K})$ & 298 & 298 \\
$\mathrm{~A}(\mathrm{~L} / \mathrm{g})$ & 0.29 & 4.02 \\
$\mathrm{~b}(\mathrm{~J} / \mathrm{mol})$ & 3260 & 35907 \\
$\mathrm{R}^{2}$ & 0.886 & 0.742 \\
\hline
\end{tabular}

Adsorption kinetics: The reaction kinetics of the adsorption process was evaluated using the model based approach. The experimental data was fitted to two models, pseudo first-order kinetics and the pseudo second-order kinetic models which have been used to describe the kinetics of metal ion adsorption processes [21-23].

Pseudo first-order kinetics: The adsorption process was tested for pseudo first-order kinetics by using the model [21], which can be written as follows:

$$
\log \left(q_{e}-q_{t}\right)=\log q_{e}-\frac{k_{1} t}{2.303}
$$

where $\mathrm{q}_{\mathrm{t}}$ is the amount of metal ion adsorbed $(\mathrm{mg} / \mathrm{g})$ at time $\mathrm{t}$, $\mathrm{k}_{1}$ is the pseudo first-order rate constant $\left(\mathrm{min}^{-1}\right)$. If the process follows pseudo first-order kinetics, a plot of $\log \left(\mathrm{q}_{\mathrm{e}}-\mathrm{q}_{\mathrm{t}}\right)$ against $\mathrm{t}$ (Figs. 5 and 6) should give a straight line enabling the calculation of $\mathrm{k}_{1}$ and $\mathrm{q}_{\mathrm{e}}$ from the gradient and $\mathrm{y}$-intercept, respectively. The model parameters are shown in Table-4. It can be deduced that the adsorption of either of the two metal ions at all the initial conditions used does not follow pseudo first-order kinetics because the calculated $\mathrm{q}_{\mathrm{e}}$ values do not match with the experimental values. Furthermore, the coefficients of determination are not satisfactory and the relative errors are high in the order of above 2 times.

Pseudo second-order kinetics: The pseudo second-order kinetic model [22] is given as follows:

$$
\frac{\mathrm{t}}{\mathrm{q}_{\mathrm{t}}}=\frac{1}{\mathrm{k}_{2} \mathrm{q}_{\mathrm{e}}^{2}}+\frac{1}{\mathrm{q}_{\mathrm{e}}} \mathrm{t}
$$

where $\mathrm{k}_{2}$ is the pseudo second-order rate constant ( $\left.\mathrm{g} / \mathrm{mg} \min \right)$. A plot of $t / q_{t}$ against $t$ (Figs. 7 and 8) gives a straight line that enables the determination of $\mathrm{q}_{\mathrm{e}}$ and $\mathrm{k}_{2}$ from the slope and $\mathrm{y}$-intercept, respectively. The experimental data for the adsorption of both 
TABLE-4

PSEUDO FIRST-ORDER KINETIC MODEL PARAMETERS

(Conditions: $0.8 \mathrm{~g}$ adsorbent dosage, $160 \mathrm{rpm}$ and temperature $25^{\circ} \mathrm{C}$ )

\begin{tabular}{|c|c|c|c|c|c|c|c|c|c|}
\hline \multicolumn{5}{|c|}{ Lead adsorption } & \multicolumn{5}{|c|}{ Copper adsorption } \\
\hline $\mathrm{C}_{\mathrm{i}}(\mathrm{ppm})$ & $\mathrm{q}_{\mathrm{e}, \exp }(\mathrm{mg} / \mathrm{g})$ & $\mathrm{k}_{1}\left(\min ^{-1}\right)$ & $\mathrm{q}_{\mathrm{e}, \mathrm{cal}}(\mathrm{mg} / \mathrm{g})$ & $\mathrm{R}^{2}$ & $\mathrm{C}_{\mathrm{i}}(\mathrm{ppm})$ & $\mathrm{q}_{\mathrm{e}, \exp }(\mathrm{mg} / \mathrm{g})$ & $\mathrm{k}_{1}\left(\min ^{-1}\right)$ & $\mathrm{q}_{\mathrm{e}, \mathrm{cal}}(\mathrm{mg} / \mathrm{g})$ & $\mathrm{R}^{2}$ \\
\hline 25 & 2.312 & 0.111 & 41.21 & 0.678 & 2.0 & 0.238 & 0.064 & 0.549 & 0.981 \\
\hline 20 & 1.816 & 0.032 & 1.514 & 0.954 & 1.6 & 0.190 & 0.058 & 0.360 & 0.978 \\
\hline 15 & 1.376 & 0.032 & 1.667 & 0.945 & 1.2 & 0.119 & 0.044 & 0.204 & 0.822 \\
\hline 10 & 0.972 & 0.037 & 1.469 & 0.856 & 0.8 & 0.077 & 0.021 & 0.057 & 0.974 \\
\hline
\end{tabular}

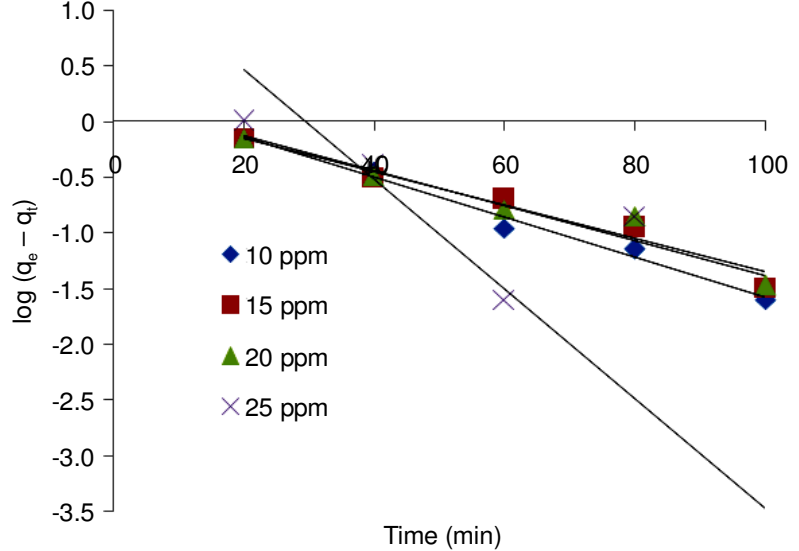

Fig. 5. Pseudo first-order plot for the adsorption of lead(II) on sodium bentonite/carbon black composite adsorbent (Conditions: $0.8 \mathrm{~g}$ adsorbent dosage, $160 \mathrm{rpm}$ at $25^{\circ} \mathrm{C}$

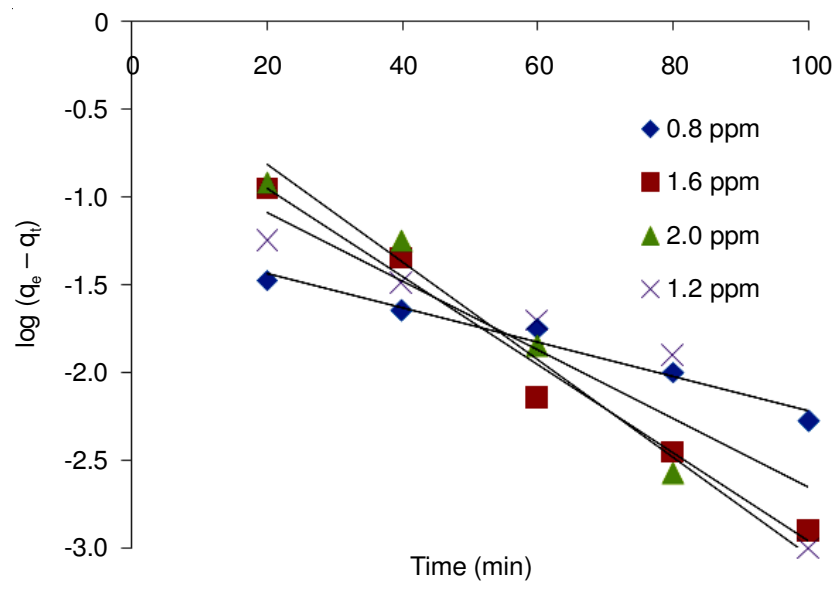

Fig. 6. Pseudo first-order plot for the adsorption of copper(II) on sodium bentonite/carbon black composite adsorbent (Conditions: $0.8 \mathrm{~g}$ adsorbent dosage, $160 \mathrm{rpm}$ at $25{ }^{\circ} \mathrm{C}$ )

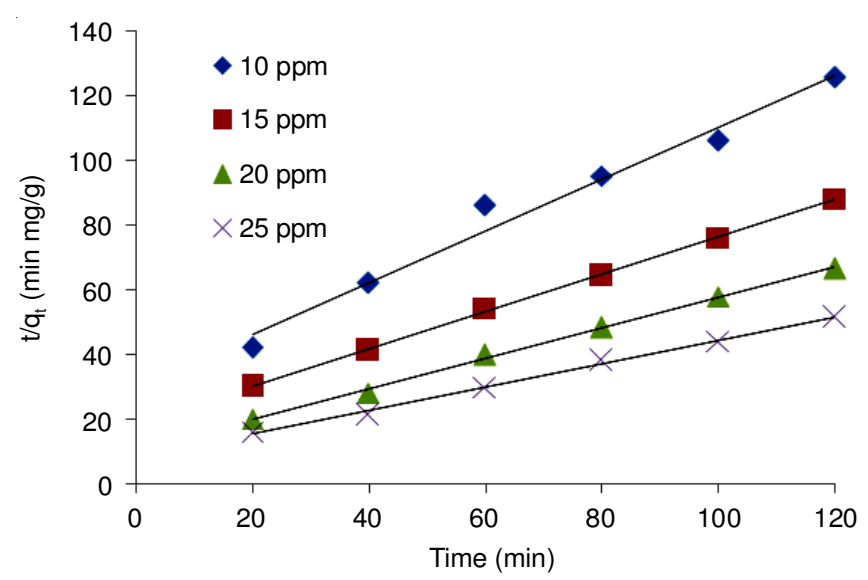

Fig. 7. Pseudo second-order plot for the adsorption of lead(II) on sodium bentonite/carbon black composite adsorbent (Conditions: $0.8 \mathrm{~g}$ adsorbent dosage, $160 \mathrm{rpm}$ at $25^{\circ} \mathrm{C}$ )

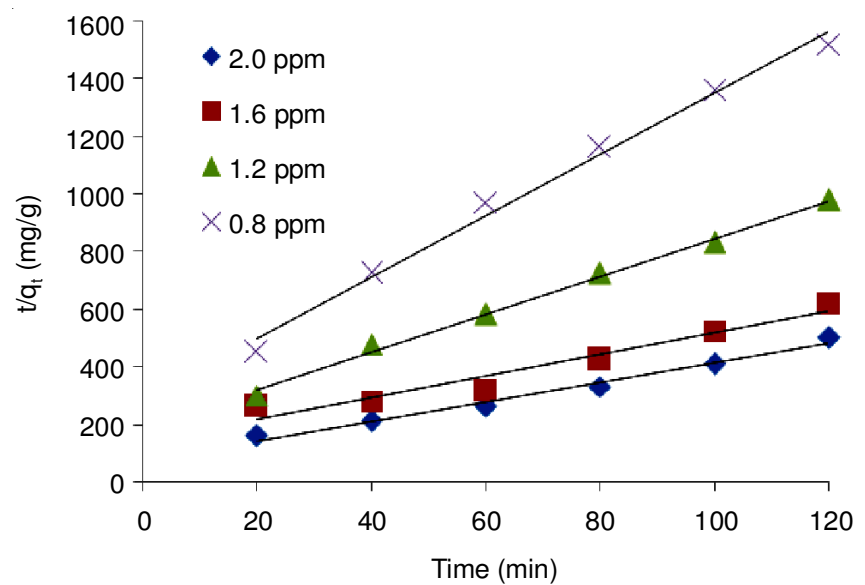

Fig. 8. Pseudo second-order plot for the adsorption of copper(II) on sodium bentonite/carbon black composite adsorbent (Conditions: $0.8 \mathrm{~g}$ adsorbent dosage, $160 \mathrm{rpm}$ at $25^{\circ} \mathrm{C}$ )

\begin{tabular}{|c|c|c|c|c|c|c|c|c|c|c|}
\hline \multicolumn{11}{|c|}{$\begin{array}{l}\text { TABLE-5 } \\
\text { PSEUDO SECOND-ORDER KINETIC MODEL PARAMETERS } \\
\text { (Conditions: } 0.8 \mathrm{~g} \text { adsorbent dosage, } 160 \mathrm{rpm} \text { and temperature } 25^{\circ} \mathrm{C} \text { ) }\end{array}$} \\
\hline $\mathrm{C}_{\mathrm{i}}(\mathrm{ppm})$ & $\begin{array}{c}\frac{1}{q_{e}} \\
(g / m g)\end{array}$ & $\delta\left(\frac{1}{q_{e}}\right)$ & $\begin{array}{c}\mathrm{q}_{\mathrm{e}, \exp } \\
(\mathrm{mg} / \mathrm{g})\end{array}$ & $\delta \mathrm{q}_{\mathrm{e}}$ & $\begin{array}{c}\mathrm{q}_{\mathrm{e}, \text { cal }} \\
(\mathrm{mg} / \mathrm{g})\end{array}$ & $\begin{array}{c}\frac{1}{\mathrm{k}_{2} \mathrm{q}_{\mathrm{e}}^{2}} \\
(\mathrm{mg} / \mathrm{g} \min )\end{array}$ & $\delta\left(\frac{1}{\mathrm{k}_{2} \mathrm{q}_{\mathrm{e}}^{2}}\right)$ & $\begin{array}{c}\mathrm{k}_{2}(\mathrm{~g} / \mathrm{mg} \\
\mathrm{min})\end{array}$ & $\delta \mathrm{k}_{2}$ & $\mathrm{R}^{2}$ \\
\hline \multicolumn{11}{|c|}{ Lead adsorption kinetics } \\
\hline 25 & 0.3601 & \pm 0.0164 & 2.312 & \pm 0.1265 & 2.778 & 7.736 & \pm 1.275 & 0.017 & \pm 0.0032 & 0.991 \\
\hline 20 & 0.4703 & \pm 0.0133 & 1.861 & \pm 0.0601 & 2.128 & 9.432 & \pm 1.035 & 0.023 & \pm 0.0029 & 0.996 \\
\hline 15 & 0.5608 & \pm 0.0137 & 1.376 & \pm 0.0436 & 1.786 & 19.62 & \pm 1.070 & 0.016 & \pm 0.0012 & 0.997 \\
\hline 10 & 0.7884 & \pm 0.0601 & 0.972 & \pm 0.0966 & 1.269 & 29.56 & \pm 4.684 & 0.021 & \pm 0.0046 & 0.977 \\
\hline \multicolumn{11}{|c|}{ Copper adsorption kinetics } \\
\hline 2.0 & 3.373 & \pm 0.2027 & 0.296 & \pm 0.0178 & 0.297 & 81.99 & \pm 15.79 & 0.139 & \pm 0.0316 & 0.985 \\
\hline 1.6 & 3.885 & \pm 0.4362 & 0.257 & \pm 0.0288 & 0.257 & 137.5 & \pm 33.97 & 0.110 & \pm 0.0367 & 0.952 \\
\hline 1.2 & 6.826 & \pm 0.2171 & 0.147 & \pm 0.0046 & 0.146 & 185.5 & \pm 16.91 & 0.249 & \pm 0.0276 & 0.996 \\
\hline 0.8 & 10.91 & \pm 0.5536 & 0.092 & \pm 0.0047 & 0.092 & 286.6 & \pm 43.12 & 0.412 & \pm 0.0750 & 0.989 \\
\hline
\end{tabular}


metal ions at all the initial concentrations fits the pseudo-second order kinetic model with a high coefficient of determination ranging from 0.952 to 0.997 . For example considering copper adsorption at an initial concentration of $0.8 \mathrm{ppm}, \mathrm{R}^{2}$ value for pseudo second-order model is 0.989 as compared to that of pseudo first-order model which is 0.974 . It can therefore, be concluded that the adsorption of the two metal ions follows pseudo second-order kinetics. The model parameters together with their margin of errors are shown in Table-5. It is clear that the experimental and calculated values of $\mathrm{q}_{\mathrm{e}}$ are in good agreement.

\section{Conclusion}

This study has shown that a composite mixture of carbon black and sodium bentonite can be used as an adsorbent for aqueous solutions containing copper and lead ions. The adsorption data was tested for Langmuir, Freundlich and Temkin isotherms. The data fitted well with the Langmuir isotherm with $\mathrm{R}^{2}$ value of 0.92 for both lead and copper adsorption. The maximum adsorption capacities for lead and copper are 7.69 and $0.80 \mathrm{mg} / \mathrm{g}$, respectively, indicating that the adsorbate is more suitable for lead adsorption. The separation factor $\mathrm{R}_{\mathrm{L}}$ was found to be 0.78 and 0.79 for lead and copper, respectively indicating favourable adsorption for both metals. Furthermore, $\mathrm{pH}$ has been shown to affect the adsorption process such that the optimum $\mathrm{pH}$ is 6 . The kinetic studies showed that the adsorption process follows a pseudo second-order model for each of the metals.

\section{ACKNOWLEDGEMENTS}

The authors are grateful to Department of Applied Chemistry, National University of Science \& Technology, Bulawayo, Zimbabwe, where most of the experimental work was carried out.

\section{REFERENCES}

1. P. Mukheibir, Environ. Manage., 45, 1027 (2010); https://doi.org/10.1007/s00267-010-9474-6.

2. E. Mekonnen, M. Yitbarek and T.R. Soreta, S. Afr. J. Chem., 68, 45 (2015); https://doi.org/10.17159/0379-4350/2015/v68a7.
3. M. Singanan, A. Abebaw and S. Vinodhini, Bull. Chem. Soc. Ethiop., 19, 289 (2005)

4. M.A.K. El Zayat, D. Phil. Thesis, Adsorption of Heavy Metals Cations in Wastewater Using Cement Kiln Dust, The American University in Cairo, Egypt (2014).

5. N.D. Tumin, A.L. Chuah, Z. Zawani and S.A. Rashid, J. Eng. Sci. Technol., 3, 180 (2008).

6. A.H.M.J.Al Obaidy, A.A.M. Al Mashhady, E.S. Awad and A.J. Kadhem, Int. J. Adv. Res., 2, 1039 (2014).

7. N.V. Hariprasad and H.S. Dayananda, Int. J. Sci. Res. Publ., 3, 1 (2013).

8. C. Zhang, F. Li and J. Xiang, Ecotoxicol. Environ. Saf., 104, 209 (2014); https://doi.org/10.1016/j.ecoenv.2014.01.008.

9. O.B. Akpor and M. Muchie, Int. J. Phys. Sci., 5, 1807 (2010).

10. P. Gehlot, K. Daga and R. Mehta, Int. J. Chem., 3, 56 (2011); https://doi.org/10.5539/ijc.v3n3p56.

11. K. Okiel, M. El-Sayed and M.Y. El-Kady, Egypt. J. Pet., 20, 9 (2011); https://doi.org/10.1016/j.ejpe.2011.06.002.

12. P. Malakul, K.R. Srinivasan and H.Y. Wang, Appl. Environ. Microbiol., 64, 4610 (1998).

13. J.R. Taylor, An Introduction to Error Analysis, The Study of Uncertainties in Physical Measurements, University Science Books, Sausalito, USA, edn 2, vol. 1 (1997)

14. E.A. Ofomaja, I.E. Unuabonah and N.A. Oladoja, S. Afr. J. Chem., 58, 126 (2005).

15. V.K. Garg, R. Gupta, A. Bala Yadav and R. Kumar, Bioresour. Technol., 89, 121 (2003); https://doi.org/10.1016/S0960-8524(03)00058-0.

16. B. Abdelhamid, A. Ourari and M.S. Ouali, Am. J. Phys. Chem., 1, 1 (2012); https://doi.org/10.11648/j.ajpc.20120101.11.

17. R.D. Johnson and F.H. Arnold, Biochim. Biophys. Acta, 1247, 293 (1995); https://doi.org/10.1016/0167-4838(95)00006-G.

18. J.F. Richardson, J.H. Harker and J.R. Backhurst, Coulson and Richardson's Chemical Engineering, Particle Technology and Separation Processes, Butterworth-Heinemann, Oxford, UK, edn 5, vol. 2 (2002).

19. H. Freundlich, Z. Phys. Chem., 57U, 385 (1906); https://doi.org/10.1515/zpch-1907-5723.

20. Y.S. Ho, J.F. Porter and G. McKay, Water Air Soil Pollut., 141, 1 (2002); https://doi.org/10.1023/A:1021304828010.

21. Y.S. Ho and G. McKay, Process Saf. Environ. Prot., 76B, 332 (1998); https://doi.org/10.1205/095758298529696.

22. Y.S. Ho and G. McKay, Water Res., 34, 735 (2000); https://doi.org/10.1016/S0043-1354(99)00232-8.

23. M.H. Al-Qunaibit, W.K. Mekhemer and A.A. Zaghloul, J. Colloid Interface Sci., 283, 316 (2005); https://doi.org/10.1016/j.jcis.2004.09.022. 